\title{
unindra
}

Universitas Indraprasta PGRI

Address: Jl. Nangka No. 58 C (TB. Simatupang), Kel. Tanjung Barat, Kec. Jagakarsa, Jakarta Selatan 12530, Indonesia. +62 (021)

7818718 - 78835283; url: www.unindra.ac.id; cultural.syndrome@unindra.ac.id

\section{Royal Palace Location: The Case of Sultanate of Perak}

\section{Mohd Jaki bin Mamat',}

Muhammad Firzan bin Abdul Aziz²

School of Housing, Building and Planning,

Universiti Sains Malaysia ${ }^{1,2}$

Correspondence regarding this article should be addressed to:

Mohd Jaki Bin Mamat, mohdjaki@usm.my

\section{Article History}

Received : 18-11-2020

Revised : 22-12-2020

Accepted : 24-12-2020

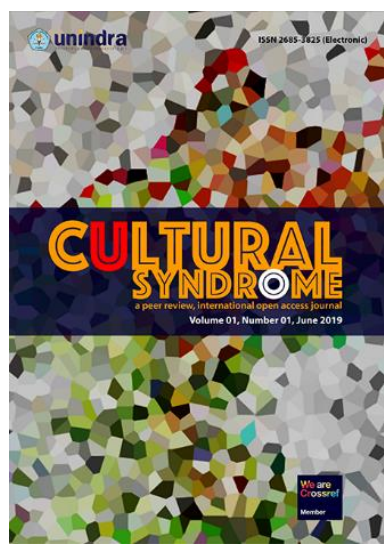

Cultural Syndrome

a peer review, internasional open access journal e-ISSN: 2685-3825

Editor: (D) Puteri Shireen Jahn Kassim

Publication details, including author guidlines https://journal.unindra.ac.id/index.php/cusy/ about/submissions\#authorGuidelines

\section{How to cite this article (MLA 8th)}

Mamat, Mohd Jaki bin and Muhammad Firzan bin Abdul Aziz. "Royal Palace Location: The Case of Sultanate of Perak." Cultural Syndrome, vol. 2, no. 2, 2020, pp. 112-122, doi: http://dx.doi.org/10.30998/cs.v2i2.518.

Universitas Indraprasta PGRI (as Publisher) makes every effort to ensure the accuracy of all the information (the "Content") contained in the publications. However, we make no representations or warranties whatsoever as to the accuracy, completeness, or suitability for any purpose of the Content. Any opinions and views expressed in this publication are the opinions and views of the authors, and are not the views of or endorsed by Universitas Indraprasta PGRI. The accuracy of the Content should not be relied upon and should be independently verified with primary sources of information.

\section{(c) (1) (\$)}

This work is licensed under a Creative Commons Attribution-NonCommercial 4.0 International License.

Copyright by Mohd Jaki bin Mamat, Muhammad Firzan bin Abdul Aziz (2020)

The authors whose names are listed in this manuscript declared that they have NO affiliations with or involvement in any organization or entity with any financial interest (such as honoraria; educational grants; participation in speakers' bureaus; membership, employment, consultancies, stock ownership, or other equity interest; and expert testimony or patent-licensing arrangements), or non-financial interest (such as personal or professional relationships, affiliations, knowledge or beliefs) in the subject matter or materials discussed in this manuscript. This statement is signed by all the authors to indicate agreement that the all information in this article is true and correct 


\title{
Royal Palace Location: The Case of The Sultanate of Perak
}

\author{
Mohd Jaki bin Mamat ${ }^{1}$, Muhammad Firzan bin Abdul Aziz ${ }^{2}$ \\ School of Housing, Building and Planning, Universiti Sains Malaysia ${ }^{1,2}$
}

\begin{abstract}
Perak's Malay Sultanate is known to have the longest root in the Malaysian Sultanate tradition with the most numbers of Sultans (35). Interestingly, 27 of them built a new palace, each for themselves, rather than using the inherited ones. However, those 27 locations of the royal palaces of the Perak's Malay Sultanate are yet to be identified and recorded. This has called upon the needs to conduct a preliminary investigation on those locations based on scrutiny of secondary data (theoretically through old manuscripts and historical writings) and primary data (empirically through interviewing local people and utilising GIS technology). Analysis based on the data triangulations hence would provide a scientific and systematic inventory of the royal palaces of Perak's Malay Sultanate.
\end{abstract}

Keywords: geomorphologic, royal palace, scientific inventory

Correspondence author: Mohd Jaki Bin Mamat, mohdjaki@usm.my, Penang, Malaysia.

\section{Introduction}

Perak's Malay Sultanate was unique in the aspect of their monarchy system whereby they practiced the throne rolling system (sequential basis from Raja Muda, Raja Bendahara to Raja Di Hilir) instead of the common hereditary system. This system consequently affected in the built of royal palaces in terms of numbers and locations. In the case of new throne successions, royal palaces of Perak's Malay Sultanate were not made as heritable monuments which was commonly practiced by other royal sultanates in Tanah Melayu. Evidently, there are 27 locations of royal palaces and administration centres recorded in old manuscripts. Based on the seminal records, the varying locations of royal palaces and administration centres started during the era of the very first sultan of Perak namely Sultan Muzaffar Shah I (1528-1549) until the 27th's sultan namely Sultan Yusuf Sharifuddin Muzaffar Shah (1877-1887). This tradition remained 
unchange only until the reign of the 28th's sultan of Perak. Eversince, the location of the royal palace has remained the same until today at Bukit Chandan, Kuala Kangsar.

Aknowledging so, it is deemed important to investigate on the vanished 27 royal palaces' locations which has never been done before. These locations carry much historical and cultural significance as they bear the architectural pride of Perak's Malay Sultanate. Hence, this conceptual paper scrutinised old manuscripts to come out with a preliminary inventory on the locations of the vanished 27 royal palaces of Perak Sultanate, prior to conduct interviews with the locals and explore archaelogical evidences in further research.

\section{Literature Review}

Understanding of an area or place should not be limited to a mere locality. Rather, such comprehension should be measurable through a place's sense of identity and psychology (Hassan and Rahman; Opp). Assertively, formation of a settlement or an administrative centre reflects its past livings and influence of its early system respectively (Ibrahim et al.). Aspects such as cultural values, life qualities, types of built material used and evolution process are imperative in researching a locality. These include anthropological theory, of historical and cultural dimensions, from a general topic to a much specific scope on buildings, craftmanships and so on (Groover; Spooner). In this sense, constant updates on historical records via proper documentations is crucial by cross-referring data from multiple sources, reading old manuscripts and historical writings, as well as interviewing the locals (Micsik and Felker; Opp; Zolkafli Umi et al.). According to $\underline{\text { Smith }}$, there are various benefits of exploring historical sites systematically such as increasing the awareness of a place's significance, bonding together the locals, improving economic gains, strengthening cultural values, enhancing sense of place, discovering new knowledge, increasing the publicity and visibility, and offering the opportunity for scientific studies.

Imperatively, the initial stage of conserving and managing a historical site is to understand its location and surrounding environment. It is deemed important prior to measuring the site capability in generating economic gains (Smith; Wang and Zan). In this regard, systematic site inventory is of the essence, especially by adopting systems which have been acknowledged and adopted for uses by official bodies from both local and international levels. Theoretically, an inventory should be focusing in a topic or a theme (Myers). This remark was influential to the current study in focusing on the location aspect to provide preliminary data for further studies and explorations. It has been argued that if any historical site is being long neglected, scientifical evidence may diminish thus halting more discoveries and understanding of a place (Chang; $\underline{\text { Starn }}$ ). Besides, the difficulties in determining appropriate methods, formulas and theories in conserving historical site would follow suit.

By definition, an inventory can be understood as a systematic management process in which a site or building is identified, understood and evaluated for its worth (Green et al.; Schuster). Eventually, the outcome would lead to a better heritage protection and conservation. Among the various approach in inventory are archival analysis, mapping 
and measuring, and inventorying buildings, artefacts and locations through surveys, archaeological works and remote sensing (Fangi et al.; Myers; Shah).

\section{Problem Statement}

Emerged in 1528 since the time of Malacca's Malay Sultanate, Sultan Muzaffar Shah became the first Sultan of Perak. In this regard, Perak's Malay Sultanate is known to have the longest root in the Malaysian Sultanate tradition. To date, Perak is known as the state with the most numbers of Sultans (35). Published evidences such as Chempaka Sari (Mohd Basri), Hikayat Misa Melayu (aja Chulan), Sejarah Perak (dㅣ), A History of Perak (Winstedt and Wilkinson), Sejarah Perak (Nasir) and Perak and the Malays (McNair) are very helpful for the current study in enlightening the locations and tombs of Perak's Malay Sultanate. The fact that almost each of the Perak's Sultan possessed their very own palace situated at varying locations made Perak's Malay Sultanate very unique. Interestingly, there were 27 Perak sultans built a new palace, each for themselves, rather than using the inherited ones.

Table 1 and Diagram 1 shows merely the 28th to the 35th sultans of Perak resided at the very same palace at Bukit Chandan, Kuala Kangsar. Implying from this, there are still 27 locations of the royal palaces of the Perak's Malay Sultanate yet to be identified and recorded. Early manuscripts reported that admistrative centres of the Perak's Malay Sultanate were located within the main traditional settlements along the Perak River that stretched from Teluk Intan to Kuala Kangsar. Thus, it is imperative to investigate on these unknown and unexplored sites and locations by undertaking a systematic and scientific inventory to address the knowledge gap, benefiting future research as well as promoting social and economical growth.

Table 1 Sequential List of Perak's Sultans

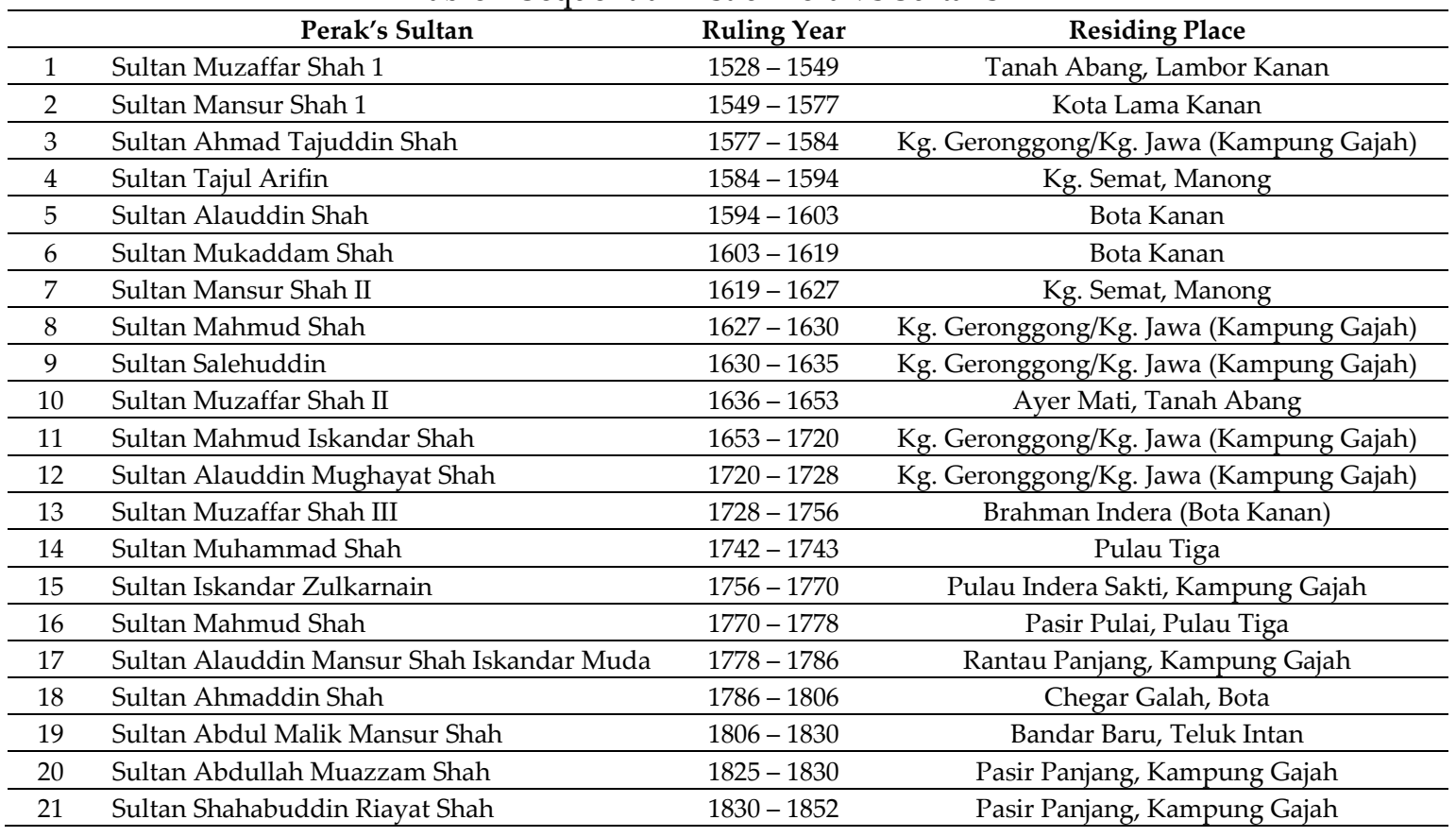




\begin{tabular}{llcc}
\hline 22 & Sultan Abdullah Muhammad Shah I & $1852-1857$ & Durian Sebatang, Teluk Intan \\
\hline 23 & Sultan Ja'far Muazzam Shah & $1857-1865$ & Pasir Pajang, Kampung Gajah \\
\hline 24 & Sultan Ali Al-Mukammal Inayat Shah & $1865-1871$ & Sayong, Kuala Kangsar \\
\hline 25 & Sultan Ismail Muabidin Riayat Shah & $1871-1874$ & Belanja, Parit \\
\hline 26 & Sultan Abdullah Muhammad Shah II & $1874-1876$ & Batak Rabit, Teluk Intan \\
\hline 27 & Sultan Yusuf Sharifuddin Muzaffar Shah & $1877-1887$ & Sayong, Kuala Kangsar \\
\hline 28 & Sultan Idris Murshidul A'zam Shah & $1887-1916$ & Bukit Chandan, Kuala Kangsar \\
\hline 29 & Sultan Abdul Jalil Nasruddin Shah & $1916-1918$ & Bukit Chandan, Kuala Kangsar \\
\hline 30 & Sultan Iskandar Shah & $1918-1938$ & Bukit Chandan, Kuala Kangsar \\
\hline 31 & Sultan Abdul Aziz Al-Mu'tasim Bi'llah Shah & $1938-1948$ & Bukit Chandan, Kuala Kangsar \\
\hline 32 & Sultan Yusuff Izzuddin Shah & $1948-1963$ & Bukit Chandan, Kuala Kangsar \\
\hline 33 & Sultan Idris AlMutawakkil Alallahi Shah & $1963-1984$ & Bukit Chandan, Kuala Kangsar \\
\hline 34 & Sultan Azlan Muhibuddin Shah & $1984-2014$ & Bukit Chandan, Kuala Kangsar \\
\hline 35 & Sultan Nazrin Muizzuddin Shah & $2014-$ & Bukit Chandan, Kuala Kangsar \\
& & present & \\
\hline
\end{tabular}

Table 1 and Figure 3 indicated that the royal palaces of Perak's Malay Sultanate are concentrated at several locations such as Teluk Intan, Kampung Gajah, Bota Kanan, Kota Lama Kanan, Parit dan Kuala Kangsar (Manong dan Sayong). Despite located within the similar area or region, it is important to note that the royal palaces were built at varying locations. Hence, identification of the exact sites and locations of the royal palaces within the area or region through systematic inventory would be beneficial.

However, the identification process would be challenging since the royal palaces were in close proximity with river which geographic transformation has been always rapid due to climatic influence. In this sense, transformation of the river must be deliberately accounted and cross-referenced with reports from documented sources, and, findings from interviews with the locals.

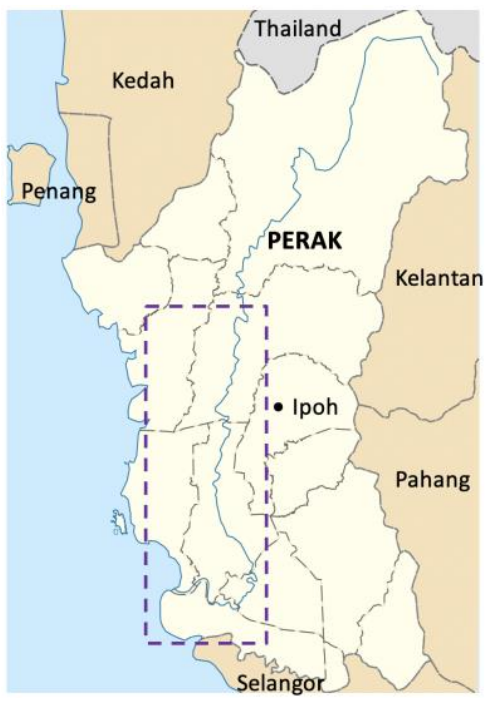

Figure 1 Current map: The residing place of Perak's Malay Sultanate along Perak River.

Note: Ipoh is Capital State of Perak 


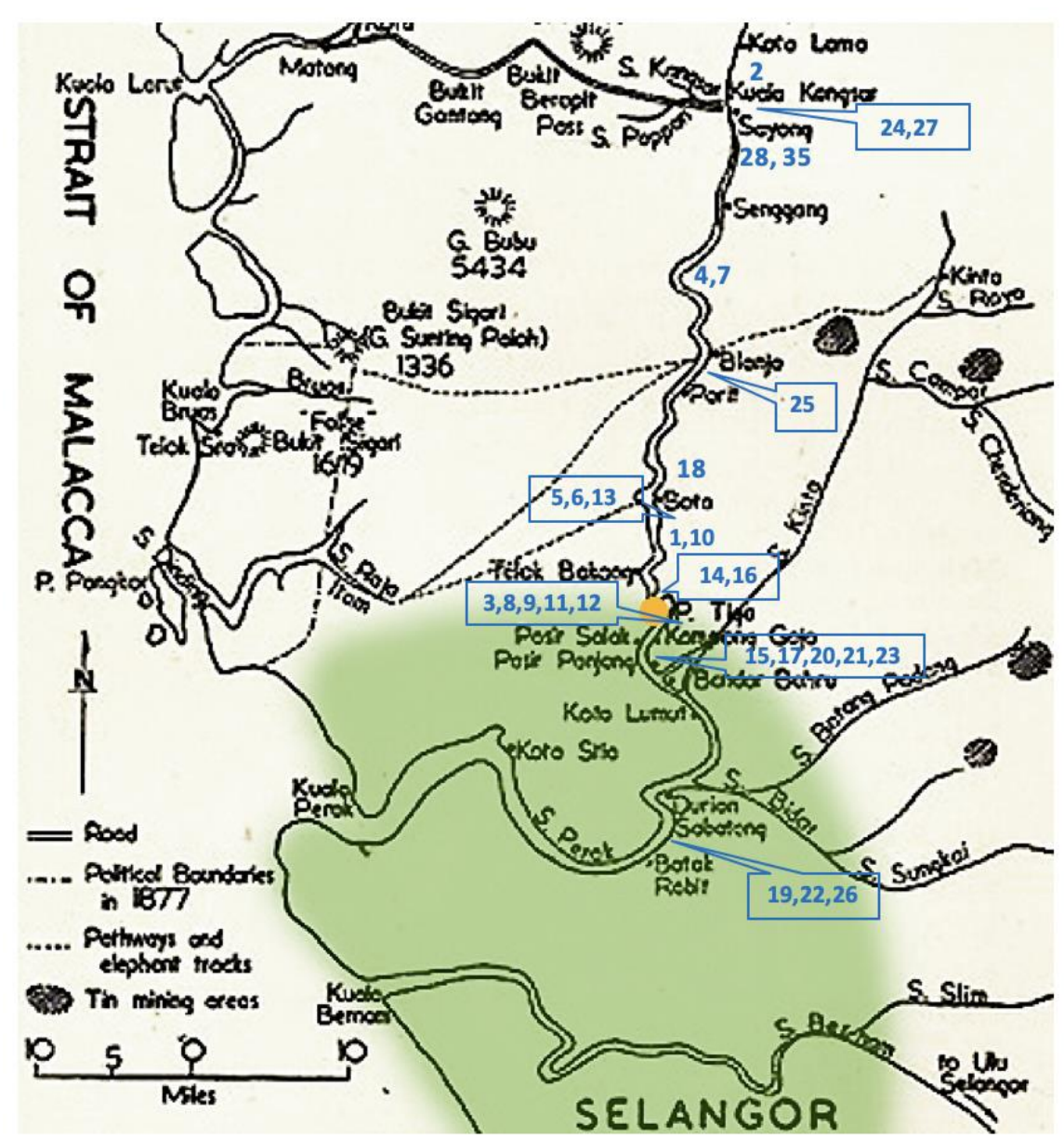

Figure 2 Old Map (1877): Map of the residing place of Perak's Malay Sultanate.

\section{Objectives of the Study}

1. To identify the locations of the royal palaces of Perak's Malay Sultanate.

2. To identify the change of pattern for the locations (administration centres and royal palaces).

3. To interpret the dispersion of the administration centres using spatial distribution analysis with the purposes of:

a. Interpreting spatial distribution of each administration centres, individually and as a whole.

b. Understanding the pattern of the administration centres whether scattered or centralised for their planning system

c. Looking at the influence of geographical and geomorphological traits in choosing the locations of administrative centres.

4. Identifying the inter-relationships between the administration centres.

5. To provide a map on the locations of the vanished royal palaces of Perak's Malay Sultanate. 


\section{Methods}

Both laboratory work and field work were involved in the current study. The laboratory work comprised of two sequential categories namely Lab I (identification of locations based on interviews as well as old manuscripts and historical writings) and Lab II (remote sensing to analyse geomorphology of areas in terms of vegetations and tropographical aspects as well as colour tones). Upon the identification of the locations from Lab I, geometric physical changes of those locations were scrutinised and further understood based on satellite images for Lab II. This remote sensing method enabled in the identification of geographical and geomorphological changes of the identified locations, through the difference in forms and patterns of their past and present states.

Field work was then carried based on the remote sensing data. During this phase, physical evidences of the geographical and geomorphological changes were useful to indicate the human existence, intervention and settlement at the identified locations. Those locations were then marked based on their Global Positioning System (GPS) information encompassing latitude, longitude and altitude data.

The GPS data acquired were then analysed in the Lab II stage, through Geographic Information System (GIS) using ArcGIS software. Understanding the relationships of the historic sites and settlements with their past geographic and geomorphologic traits was the essence of undertaking such analysis. Following seminal claims that all royal palaces of the Perak's Malay Sultanate were located along or in close proximity with the river, determination on the distance between the identified locations with Perak River (was the main transportation network system back then) was made possible through spatial distribution analysis. Besides, the distribution of the royal palaces location and administration centres can also be interpreted based on the sites' area measurement as well as their physical patterns (such as scattered or centralised).

The spatial distribution analysis using GIS is deemed significant to assist in interpreting the factors of selecting admistrative locations in the past as well as their inter-relationships. Moreover, other potential sites for further exploration can also be discovered indirectly using GIS.

\section{Research Hypothesis}

Based on derivation from seminal studies, there are several hypothesis to be proven in the current ongoing study as following;

1. Presence of the 27 royal palaces (administration centres) of Perak's Malay Sultanate;

2. All of the past admistration centres were located either along or in close proximity to the Perak River, stretching about 120 kilometres from Teluk Intan to Kuala Kangsar;

3. Archaelogical and geomorphological information are indicative of the site locations;

4. Past administration centres were influenced by geographical factor;

5. River system was influential to the local economy as well as in determining administration locations. 


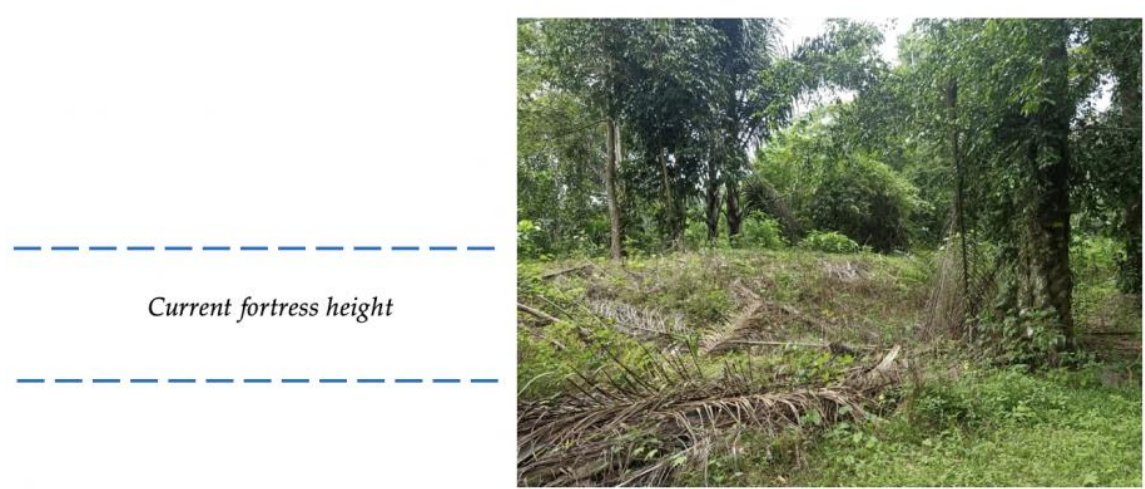

Figure 3 Compact sand wall (fortress) surround the palace compound of 1st Perak Sultan (Sultan Muzaffar Shah 1)

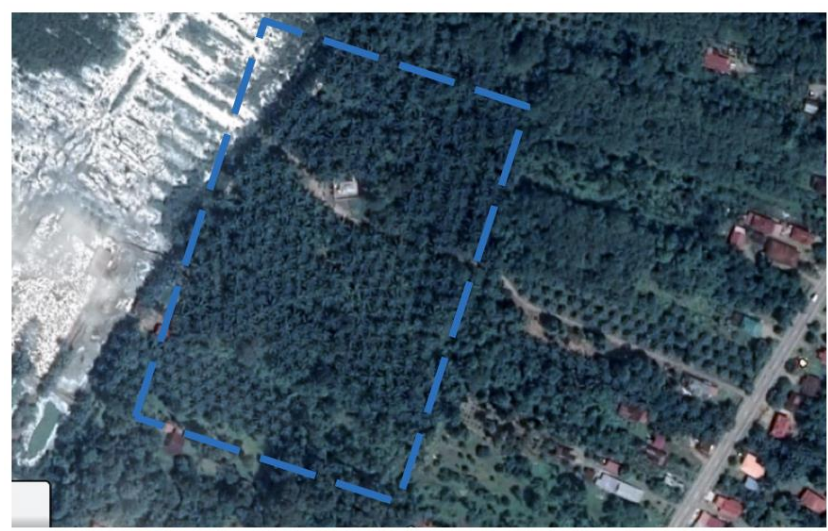

Figure 4 Stick ruler indicate compact sand wall at 1.5 meters, it believed the wall built up to 5meter hight (Sultan Muzaffar Shah 1)

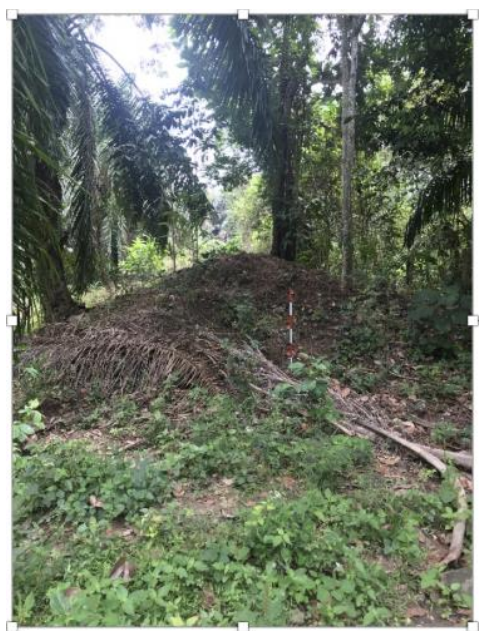

Figure 5 Dotted line indicates the fortress surround the palace compound of 1st Perak Sultan. Source: Google Map 


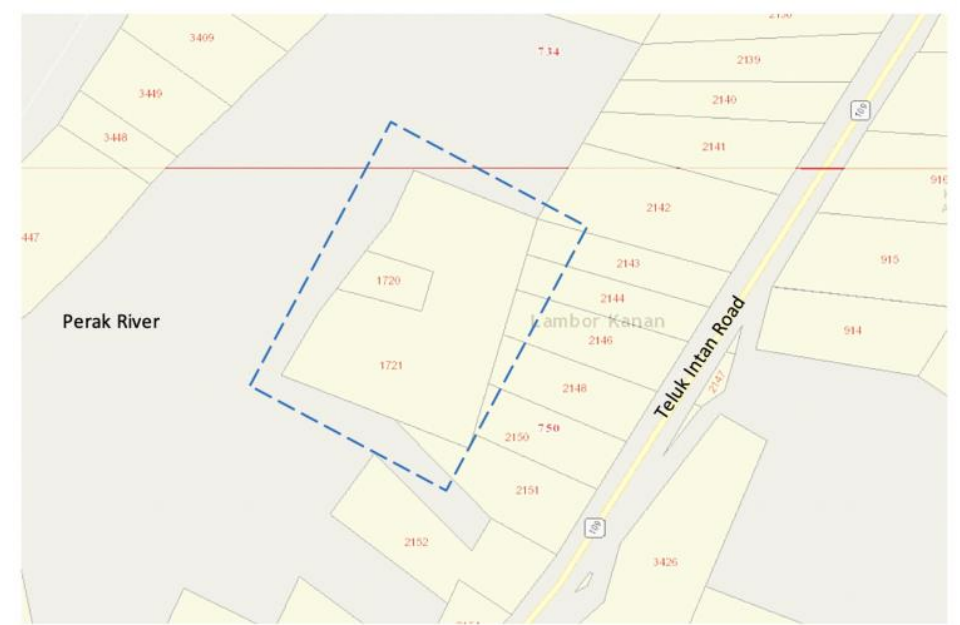

Figure 6 Land plot by Department of Survey and Mapping Malaysia; Lot 1720 is the tomb of Sultan Muzaffar Shah 1 (1st Sultan of Perak)

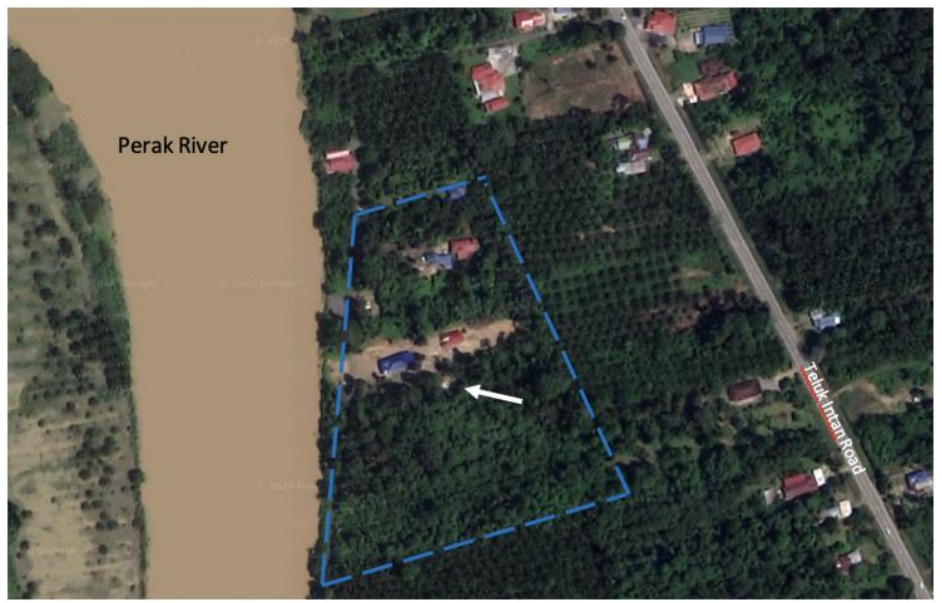

Figure 7 Current palace compound of Sultan Ahmad Tajuddin Shah (3rd Sultan of Perak). Arrow indicates the tomb of Sultan Ahmad Tajuddin Shah Source Google Map

\section{Result and Discussion}

The throne rolling system of Perak's Malay Sultanate has resulted in the construction of royal palaces that uniquely catered the needs of respective sultans during that era. Potential knowledge discovery that can be leveraged for socioeconomic gains is halted since the record on the 27 royal palaces is absence. This is considerably a huge loss to Perak's heritage asset. For instance, valuable information such as the physical fabric (architectural, built material, technological and cultural aspects), site planning, building orientation and nearby amenities of the royal palaces are no longer available with the loss of the 27 locations of the royal palaces of the Perak's Malay Sultanate.

Moreover, retrieval of the 27 locations of the royal palaces of the Perak's Malay Sultanate would also contribute in the understanding of the planning and morphological factors such as past settlements, defense mechanism and transportation system that 
support the administration centers during that era. By looking at the chronology and development of social and economic aspects of the past, this study will shed some light on the former role of royal palaces which has shaped today's scene.

It is presumed that from the archeological facet, the proposed identification and excavation means to be implemented in this study can lead to the finding of old artefacts which may lead to further discoveries such as cultural characteristics and technological advancement associated with the royal palaces of the Perak's Malay Sultanate. Such discoveries are scientific proofs which can be correlated or strengthen other seminal findings (that are available in oral and manuscripts forms).

This study is also significant from the geographical point of view. It is apparent that geographical and topographical factors are influential in the determination and selection of location for past administration centers of Perak. The entire royal palaces of the Perak's Malay Sultanate are situated along the Perak River, affirming it as Perak's main transportation and network system during the era. Besides trading activities, defense system was also formed at Perak River to fort the royal palaces of the Perak's Malay Sultanate.

This study supports the endeavors to manage cultural and heritage resources by correlating historical information with scientific evidence. Understanding of such aspects are imperative to foster heritage tourism which is an emerging industry highlighting local culture and historical importance of the country. It is in line with other vital measures that can boost the tourism industry such as conservation, place marketing, enriching the local communities etc.

Miscellaneous issues such as site ownership, change of use and dysfunctionality of the royal palaces will also be covered indirectly through the scope of this study. Some anticipated future challenges that may hinder the revival of the royal palaces of the Perak's Malay Sultanate are oil palm plantation and agricultural activities as well as afforestation. Implying from that, the study would go beyond merely identifying the locations of the royal palaces of the Perak's Malay Sultanate by scrutinizing on legislation and land ownership matters of those sites.

\section{Conclusion}

Challenges such as lack of information and accessibility predicaments to study the locations of the royal palaces of the Perak's Malay Sultanate are not an excuse to undertake this study. It is imperative to identify those locations considering the precious significance of those sites in terms of architectural, historical, cultural, and political aspects. Hence, the absence of documentation and record on the locations of the royal palaces of the Perak's Malay Sultanate should be addressed in a timely manner, as delaying the retrieval of those locations may cause more difficulties to do so as time goes by. Apparently, merely depending on seminal sources such as old manuscripts and historical writings would not suffice in providing the exact locations of the royal palaces of Perak's Malay Sultanate. To complement the secondary data, a systematic 
investigation through conducting an inventory is of the essence, which can be based on interviews with the locals as well as utilization of GIS technology. By doing so, a more scientific results based on empirical evidence can be obtained. Conclusively, triangulations of both primary and secondary data would result in the provision of the inventory on the royal palaces of Perak's Malay Sultanate.

\section{Acknowledgements}

The author would like to express gratitude to Universiti Sains Malaysia (USM) who had funded this study (short term grant; 304/PPBGN/6315216) as well as other various parties contributing to the success of the current study especially Perak State Museum Board, Perak Heritage Society and several individuals who were directly or indirectly involved.

\section{References}

Adil, Haji Buyong Bin. Sejarah Perak. 2 edition, Dewan Bahasa dan Pustaka, Kementerian Pelajaran Malaysia, 1982.

Chang, Bo. "Finding Empathy in Historical Inquiry and Data Management through an Educational Research Example." Qualitative Report, vol. 21, no. 8, 2016.

Fangi, Gabriele et al. "Spherical Photogrammetry as Rescue Documentation for the Reconstruction of Some Unesco Sites in Syria." International Journal of Heritage in the Digital Era, vol. 2, no. 3, 2013, pp. 335-341, doi:https://doi.org/10.1260/20474970.2.3.335.

Green, William et al. "Alfred W. Bowers' History of the Mandan and Hidatsa: A Significant Resource for Plains Anthropology." Plains Anthropologist, vol. 63, no. 246, 2018, pp. 113-133, doi:https://doi.org/10.1080/00320447.2017.1415652.

Groover, Mark D. "Assessing Historical Archaeology Site Significance in Cultural Resource Management." North American Archaeologist, vol. 34, no. 3, 2013, pp. $269-$ 291, doi:https://doi.org/10.2190/NA.34.3.c.

Hassan, Azizul and Mizan Rahman. "World Heritage Site as a Label in Branding a Place." Journal of Cultural Heritage Management and Sustainable Development, vol. 5, no. 3, 2015, pp. 210-223, doi:https://doi.org/10.1108/JCHMSD-01-2014-0002.

McNair, John Frederick Adolphus. Perak and the Malays: "Sārong" and "Krīs.". Tinsley Brothers, 1878. 
Micsik, András and Tamás Felker. "Enabling Research of Cultural Heritage and Recent History Using Courage Linked Data Registry." the 14th International Conference on Semantic Systems Co-Located with the 14th International Conference on Semantic Systems (SEMANTiCS 2018), edited by Ali Khalili and Maria Koutraki, CEUR Workshop Proceedings (CEUR-WS.org), 2018 2018, pp. 1-4. http://ceurws.org/Vol-2198/paper 105.pdfhttp://ceur-ws.org/Vol-2198/paper 105.pdf.

Mohd Basri, M. A. Fawzi. Cempaka Sari: Sejarah Kesultanan Negeri Perak. Yayasan Perak, 1986.

Myers, David. "Heritage Inventories: Promoting Effectiveness as a Vital Tool for Sustainable Heritage Management." Journal of Cultural Heritage Management and Sustainable Development, vol. 6, no. 2, 2016, pp. 102-112, doi:https://doi.org/10.1108/JCHMSD-02-2016-0009.

Nasir, Abdul Halim. Sejarah Perak Siri Pertama: Zaman Pra-Sejarah Hingga Zaman Kedatangan Pengaruh Orang Luar. Jabatan Muzium, 1977.

Opp, James. "Public History and the Fragments of Place: Archaeology, History and Heritage Site Development in Southern Alberta." Rethinking History, vol. 15, no. 2, 2011, pp. 241-267, doi:https://doi.org/10.1080/13642529.2011.564830.

Raja Chulan, bin Raja Ahmad. Misa Melayu. Pustaka Antara, 1962.

Schuster, J. Mark. "Making a List: Information as a Tool of Historic Preservation." Economics of Art and Cultureinvited Papers at the 12th International Conference of the Association of Cultural Economics International, edited by A. Ginsburgh Victor, vol. 260, Emerald Group Publishing Limited, 2003, pp. 221-240. Contributions to Economic Analysis, https://doi.org/10.1108/S0573-8555(2003)0000260017.

Shah, Khushi. "Creation of Cultural Heritage Inventories: Case of the Historic City of Ahmadabad." Journal of Cultural Heritage Management and Sustainable Development, vol. 6, no. 2, 2016, pp. 166-194, doi:https://doi.org/10.1108/JCHMSD-02-2016-0011.

Smith, Stephen. "A Sense of Place: Place, Culture and Tourism." Tourism Recreation Research, vol. 40, no. 2, 2015, pp. 220-233, doi:https://doi.org/10.1080/02508281.2015.1049814.

Spooner, Marc. "A Life History of Place: A Future Place for Life Histories?" Qualitative Inquiry, vol. 25, no. 5, 2019, pp. 513-522, doi:https://doi.org/10.1177/1077800418817840. 
Starn, Randolph. "Authenticity and Historic Preservation: Towards an Authentic History." History of the Human Sciences, vol. 15, no. 1, 2002, pp. 1-16, doi:https://doi.org/10.1177/0952695102015001070.

Wang, Tao and Luca Zan. "Management and Presentation of Chinese Sites for Unesco World Heritage List (Uwhl)." Facilities, vol. 29, no. 7/8, 2011, pp. 313-325, doi:https://doi.org/10.1108/02632771111130924.

Winstedt, R. O. and R. J. Wilkinson. "A History of Perak." Journal of the Malayan Branch of the Royal Asiatic Society, vol. 12, no. 1 (118), 1934, pp. v-180, JSTOR, http://www.jstor.org/stable/41559831.

Zolkafli Umi, Kalsum et al. "Restoration of Historical Timber Building: A Malaysian Case Study." Structural Survey, vol. 33, no. 4/5, 2015, pp. 309-321, doi:https://doi.org/10.1108/SS-01-2015-0004. 